vised, but it could not have been freer of all traces of former occupation if it had been thoroughly swept up the day before. Only once was it that a doubt crossed my mind, when I came across a cairnlike monument which looked as though it might have been constructed by human hands. But the possibility of its being the result of erosion is also quite as strong as the other. No bits of pottery, no broken household utensils of any sort, no traces of construction of any sort were visible, not even the deepening of the natural surface of any of the rock cavities for the purpose of rainwater storage for drinking use, betrayed even the slightest indication that the top of the Mesa had ever been the prehistoric home of the Acomas."

In Harper's Weekly (August 28) Professor Libbey makes the following statement:

"There were no remnants of pottery, or fragments of household utensils, or implements of any kind; no water-tanks for the storage of rain water; one object alone looked as though it might have been built by human hands, and that was a small cairnlike mass of stones."

In this article Professor Libbey pictures the operation of his gun, boatswain's chair, etc.; but where is the 'cairnlike mass of stones' which he found, the origin of which he seems to be at such a loss to determine? It seems to me that this doubtful feature is the most important of all the observations made by Professor Libbey during his brief stay on the summit, and yet he left it unphotographed.

Later, in the Philadelphia Press (October 10), Professor Libbey says :

"The cairn-like pile of rocks, which I am glad Mr. Hodge so clearly decides is a cairn, is possibly the best proof of a mere visit, for even primitive people are not given to building cairns in their back yards. ****

"I am inclined from the facts which I was able to observe upon the top of the Mesa still (!) to believe that while the top may have been visited, no evidence exists at present of its ever having been permanently inhabited.

"I picked up some fragments which resembled ancient pottery, but could not persuade myself that they were. I took them to Mr. Pearce [one of the reporters who accompanied
Professor Libbey], and he agreed with me that they were not pottery."

The fact that the Professor fails to speak of having occupied part of his precious two hours in the erection of the lichen-covered rock-pile which we found and photographed, and the fact also that the structure occurs on a spot so protected from the surface wash that it may have stood there for ages, were sufficient to mislead anyone, and my error may be regarded as acknowledged when Professor Libbey states openly that the monument was erected by himself.

The better part of two days of research by the members of my party, each of whom had his eyes open, failed to reveal any other artificial monument than the one which $I$ have figured. I am, therefore, safe in concluding that there is no ground whatever for the belief that any other artificial cairn or cairn-like structure exists on the summit of the Enchanted Mesa. If Professor Libbey constructed the cairn referred to, then he might have spent the portion of the two hours consumed by its erection in a way more profitable to archæology. Whether or not it was erected by him, the evidence of the former occupancy of the summit of the Enchanted Mesa is not weakened in the slightest degree.

\section{BUReaU of American EthNology,} F. W. HODGE. Washington, December 14, 1897.

\section{LAMARCK AND THE 'PERFECTING TENDENCY.'}

IN preparing some lectures on the history of evolution theories I have come across a curious difference of opinion among distinguished writers. Professor Osborn ('From the Greeks to Darwin,' p. 163) seems to contradict himself in the same paragraph. He says: "Lamarck believes that we see in nature a certain natural order imposed by its Author, which is manifested in the successive development of life; we thus study natural forces and nature abandoned to its laws. In this sense we see nature creating and developing without cessation towards higher and higher types. External conditions do not alter this order of development, but give it infinite variety by directing the scale of being into an infinite number of branches." 
This statement might, without violence, be paraphrased by saying: "Lamarck believed in a tendency toward perfection, modified by external conditions;" which I believe to be strictly correct. But Professor Osborn's next sentence is: "Lamarck denied, absolutely, the existence of any 'perfecting tendency' in nature, and regarded evolution as the final necessary effect of surrounding conditions on life."

On looking up other writers I found that a belief in a perfecting tendency is ascribed to Lamarck by Lyell (Principles, Vol. II., p. 259), Darwin (Origin, Amer. ed., I., pp. xv+153, and Life, I., p. 384), Spencer (Biology, Section 146), Romanes (Darwin and after Darwin, I., p. 255). Perrier (Phil. Zool. avant Darwin, p. 84) argues strongly on the same side. Strangely enough, Quatrefages (Darwin et ses Précurseurs Français, p. 65) takes quite the opposite view, and directly accuses Darwin of error. I have been unable to consult any of Lamarck's works except the Philosophie Zoologique, but so far as that is concerned the majority view seems to be the correct one. Throughout, though Lamarck does not exactly use the expression 'perfecting tendency,' he distinguishes between two things-one, the échelle, the dégradation or gradation of organisms, their tendency to composition (complication, advancement); the other, the influence of environment in altering their needs and thus their structure. The échelle is a pre-established order through which organisms have progressively evolved, but visible only in its grand outlines, because changing conditions have indirectly altered the form of the organisms, especially externally, and thus obscured the details.

A pre-established order of evolution from the lowest to the highest forms seems to amount to the same thing as a tendency towards perfection.

I have been unable to find any passages which can be construed as an absolute denial of a perfecting tendency, but I have found a good many which indicate that Lamarck believed in it; whether or not because he was unable to suggest anything better to account for the progressive evolution which he saw, who can say? The following are sufficiently good examples :
"La puissance absolue du sublime Auteur de toutes choses, n'a-t-elle pu créer un ordre de choses qui donnât successivement l'existence à tout ce que nous voyons comme à tout ce qui existe et que nous ne connaissons pas?" (Phil. Zool. ed. 1873, I. p. 74.)

"Je vais faire voir que la nature en donnant, a l'aide de beaucoup de temps, l'existence à tous les animaux et à tous les végétaux, a réellement formé dans chacun de ces régnes une véritable échelle, rélativement à la composition croissante de l'organisation de ces étres vivants, mais que cette échelle, qu'il s'agit de reconnaître, en rapprochant les objets, d'après leursrapports naturels, n'offre des degrès saisissables que dans les masses principales de la série générale, et non dans les espéces ni même dans les genres: la raison de cette particularité vient de ce que'l'extrême diversité des circonstances dans lesquelles se trouvent les différentes races d'animaux et de végétaux n'est point en rapport avec la composition croissante de l'organisation parmi eux, ce que je ferai voir, et qu'elle fait naître dans les formes et les caractères extérieurs des anomalies ou des espèces d'écarts que la composition croissante de l'organisation n'aurait pu seule occasionner." (1, c., p. 121.)

On page 144 Lamarck says: "Il est évident que si la nature n'eut donné l'existence qu'à des animaux aquatiques, et que ces animaux eussent tous et toujours vécu dans le même climat, la même sorte d'eau, la même profondeur, etc., sans doute alors on eût trouvé dans l'organisation de ces animaux une gradation régulière et même nuancée." And then he shows that differences in the composition, depth, etc., of the water have brought about disturbances in the regularity of the gradation. Lamarck invariably uses gradation in the sense of an upward series, opposing it to dégradation, a downward series.

A very important passage is that quoted by Perrier from Phil. Zool., p. 114. Lamarck states the struggle for existence according to his imperfect conception of it, showing how big and little animals alike are kept within due bounds. He concludes: "Ainsi par ces sages précautions tout se conserve dans l'ordre établi ; les changements et les renouvellements perpétuels qui 
s'observent dans cet ordre sont maintenus dans des bornes qu'ils ne sauraient dépasser; les races des corps vivants subsistent toutes, malgré leurs variations; les progrès acquis dans le perfectionnement de l'organisation ne se perdent point; tout ce qui paraît désordre, renversement, anomalie, rentre sans cesse dans l'ordre général et même y concourt; et partout et toujours la volonté du sublime Auteur de la nature et de tout ce qui existe est invariablement exécutée." Lamarck rather rarely uses the word perfectionnement; hence I have italicized it.

The passage concerning the aquatic animals very clearly shows a belief in a tendency toward perfection apart from other factors. The other passages, especially the last, are fully confirmatory.

I have been unable to consult the Histoire Naturelle, except as quoted by Professor Osborn and others. Possibly it is there that Professor Osborn finds authority for the statement that Lamarck denied absolutely the existence of a perfecting tendency. But so far as the Philosophie Zoologique is concerned the case is clear.

The point $I$ have raised is important now only as a matter of history, but in the interest of accuracy it seems desirable that Lamarck's true views should be emphasized. It would appear that he was not 'completely carried away with the belief that his theory of the transmission of acquired characters was adequate to explain all the phenomena' (Osborn l. c., p. 180); rather, the 'Lamarckian factor' played a subordinate part in his scheme of evolution. And, if this interpretation be correct, it would seem that Darwin's criticisms of Lamarck are more nearly just than is generally supposed, and that, as Perrier says, he was, 'by an astonishing contradiction, at once a finalist in his general views, and a determined opponent of final causes in details.'

JoHN GARDINER.

University of Colórado, Boulder, Colo.

MEMORIAL MEETING COMMEMORATIVE OF ALLEN AND HORN.

A GENERAL invitation is extended to all those interested to be present at a memorial meeting, commemorative of Harrison Allen, M.D., and
George H. Horn, M.D., to be held in the library hall of the Academy of Natural Sciences of Philadelphia, on Friday evening, December 31st, at eight o'clock. The following gentlemen will make addresses :

Dr. Edw. J. Nolan, 'The Relations of Doctors Allen and Horn to the Academy and other Societies.'

Mr. S. N. Rhoads, 'Dr. Allen's Work in Zoology.'

Dr. D. G. Brinton, 'Dr. Allen's Contributions to Anthropology.'

Professor John B. Smith, Sc.D., 'Dr. Horn's Contributions to Coleopterology.'

Rev. Henry C. McCook, D.D., 'Dr. Horn as a Physician and Naturalist.'

E. G. Conklin, Ph.D.,

J. Cheston Morris, M.D.,

D. G. BRINTON, M.D.,

Rev. Henry C. McCook, D.D.,

HeNRY Skinner, M.D., $C h ' m$.

Committee.

The Adademy of Natural Sciences

of PHilladelphia, LOGAN SQUARE.

\section{SCIENTIFIC LITERATURE.}

Memorials of William Cranch Bond, Director of the Harvard College Observatory 1840-1859, and of his son, George Phillips Bond, Director of the Harvard College Observatory 1859-1865. EdwaRd S. Holden. San Francisco. 1897. Pp. iii+296. 8oc. With illustrations.

In this work Professor Holden has given a most interesting account of the two men who established the Observatory of Harvard College and carried it on for its first quarter of a century-a time of great importance for the development of astronomy in this country.

In 1840 the beginnings of permanent observatories in this country had already been made; in 1865 the Observatory at Cambridge had acquired, under the Bonds, a recognized position in the astronomical world, and the Bonds had contributed to the general progress of the science.

Professor Holden's work has been rendered important, and at the same time difficult and thankless, by circumstances which he finds 